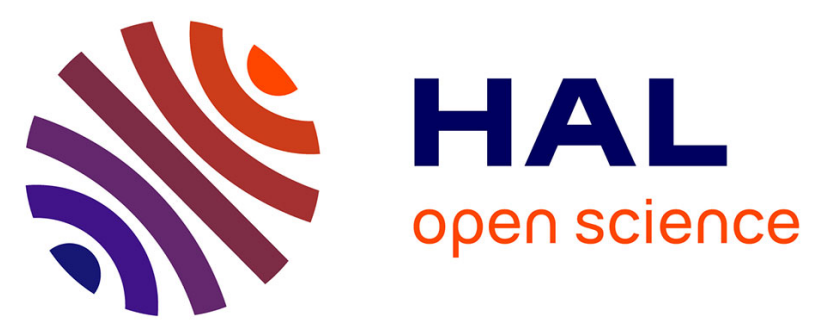

\title{
Norms, advice networks and joint economic governance: the case of conflicts among shareholders at the commercial court of Paris
}

\author{
Emmanuel Lazega, Lise Mounier, Paola Tubaro
}

\section{- To cite this version:}

Emmanuel Lazega, Lise Mounier, Paola Tubaro. Norms, advice networks and joint economic governance: the case of conflicts among shareholders at the commercial court of Paris. Ugur Mehmeth, Sunderland David. Does Economic governance matter? Governance Institutions and Outcomes, Edward Elgar Publishing, pp.46-70, 2011. hal-01054015

HAL Id: hal-01054015

https://hal-sciencespo.archives-ouvertes.fr/hal-01054015

Submitted on 4 Aug 2014

HAL is a multi-disciplinary open access archive for the deposit and dissemination of scientific research documents, whether they are published or not. The documents may come from teaching and research institutions in France or abroad, or from public or private research centers.
L'archive ouverte pluridisciplinaire HAL, est destinée au dépôt et à la diffusion de documents scientifiques de niveau recherche, publiés ou non, émanant des établissements d'enseignement et de recherche français ou étrangers, des laboratoires publics ou privés. 


\title{
3. Norms, advice networks and joint economic governance: the case of conflicts among shareholders at the Commercial Court of Paris
}

\author{
Emmanuel Lazega, Lise Mounier and
} Paola Tubaro

\section{INTRODUCTION}

Businesses are usually very keen to participate in the governance of their markets (Lazega and Mounier, 2002, 2003; Falconi et al., 2005). In this chapter, we combine a sociological perspective on joint governance of markets with an economic perspective, such as that of Dixit (2009) that deals with issues of social optimality of private or public governance and enforcement institutions. Institutional and neo-institutional economic theory often separate official governance institutions from private self-governance (Greif, 1996; Ellickson, 1991; Milgrom et al., 1990; Williamson, 1985). At the inter-organizational level, at least two different sociological traditions also deal with the issue of self and exogenous governance of markets, comparing the formal and often exogenous aspects with informal and endogenous ones.

In the socio-legal approach, exogenous governance (see for example Ayres and Braithwaite, 1992; Hawkins, 1984; Hawkins and Thomas, 1984; Shapiro, 1984; Weait, 1993; Weaver, 1977) is provided by government agencies backed up by courts. These studies focus, for example, on the decision by government agencies to prosecute deviant companies. Such decisions are not straightforward and may often be endogenous outcomes of the interaction between official inspectors and company managers. This is especially the case when strict enforcement of the law is associated with large risks emanating from large-scale losses and layoffs, and sometimes bankruptcy.

The second tradition focuses on self-governance mechanisms usually legitimated by state backing - that is, on inter-firm arrangements that 
provide self-governance and informal conflict-resolution mechanisms that govern inter-firm and firm-stakeholder transactions. Because litigation is costly, firms usually prefer unofficial dispute resolution whenever possible, especially when they have long-term continuing relationships (see for example Macaulay, 1963, 1986; Raub and Weesie, 1993, 2000; Rooks et al., 2000; Buskens et al., 2003); or as Dixit (2009) has indicated, when private-ordering governance institutions evolve to replace formal governance institutions that may sometimes be less efficient. Here the focus is on pressures to conform and the latter is shaped by resource dependencies, inter-dependence and reputation. Thus, these two traditions focus on different kinds of actors intervening in governance, the state and companies themselves - the latter sometimes through industry representatives.

In reality, the two forms of governance systems coalesce in various ways. One possible combination is Ayres and Braithwaite's 'responsive self-governance' (1992), acknowledging the existence of 'enforcement pyramids' that exist between governmental regulatory agencies and corporate actors and provide the opportunity to escalate from persuasion to warning letters to civil fines and criminal penalties to license suspension and revocation. Actors are aware of such enforcement pyramids, and know that an escalation can be triggered. This is why, in spite of costs, firms do use litigation both as plaintiffs and as defendants (Galanter and Epp, 1992; Dunworth and Rogers, 1996; Cheit and Gersen, 2000), and conflicts follow the disputing pyramid transforming informal complaints into court filings and formal judiciary decisions (Felstiner et al., 1980).

We further explore the idea that the two forms of governance are connected and that there can be 'joint' governance or a combined regime of endogenous and exogenous business conflict resolution. This can take many hybrid forms, and the joint element is defined as the coexistence of several sources of constraint, both external and internal, that weigh on the actors in charge of solving conflicts and enforcing rules. Specifically, we identify a form of joint governance in the case of a 'consular' court in which judges are business people elected by their peers, and serve as unpaid volunteers.

Courts are not static institutions making a-temporal and purely rational decisions (Heydebrand and Seron, 1990; Wheeler et al., 1988). Rather, they constitute a contested terrain, the prize or object of broader economic competition and conflict that occur outside them (Flemming, 1998). This is especially the case in consular courts, where judges can be regarded both as official third parties upholding legal rules and procedures in conflict resolution processes; and as unofficial and potential levers of influence representing their industry of origin, thereby possibly favouring outcomes that do not hurt the interests of this industry. As levers, they can sometimes 
weigh on judicial decisions directly, or do so indirectly by gaining other judges' consent on specific outcomes.

Thinking about joint governance in these terms follows both an organizational and a broadly conceived organizational and structural approach to economic institutions (Lazega and Mounier, 2002, 2003; Dixit, 2009) in which network analysis is used to study actors' resource interdependencies. ${ }^{1}$ We use this twofold perspective to contribute to the study of economic and legal institutions that combine exogenous and self-governance of markets. On the basis of an empirical network survey combined with a jurisprudential study, we examine the first commercial court in France, a consular court to which the state delegates conflict-resolution powers with respect to intercompany disputes. This case provides insight into particular interests' efforts to shape the forum in which disputes between businesses are processed.

The remainder of this chapter is organized as follows. First, we describe the system of joint governance that French consular courts represent, outline the tension between particular interests and the general interest, explain how advice network data can provide insight and present our fieldwork. We then provide details of our jurisprudential study, focusing on judges' attitudes in a case of conflict between minority shareholders and the board of a company, which we use to measure judges' degree of pro-interventionism in the internal affairs of a firm. The following section presents the stochastic actor-oriented model of network dynamics that we use and our results; the final section sums up and concludes.

\section{THE COMMERCIAL COURT OF PARIS}

For five centuries, the French solution to the problem of ensuring business conflict resolution and market discipline has consisted in the government sharing its judiciary power with the business community through consular commercial courts. ${ }^{2}$ They represent a form of integration of business in the state apparatus in that judges are voluntary business people, elected for two to four years (for a maximum total of 14 years) by sitting judges and members of the Chamber of Commerce of their local jurisdiction.

Judges sit in judgment one day a week in matters of commercial litigation and bankruptcy. ${ }^{3}$ As in any other court, their decisions can be challenged and brought to the Court of Appeal, where judges are career magistrates typically trained at Ecole Nationale de la Magistrature. That challenges are relatively infrequent (about five per cent of cases) allows these consular courts to claim that this combination of external and selfgovernance of local business communities is 'efficient'.

Judges include retired businesspeople ${ }^{4}$ as well as more junior profes- 
sionals, whether bankers, lawyers, or consultants, who seek experience, status and social contacts, sometimes on behalf of their employer -who keeps paying their salary one day a week while they are practicing at the court. Sitting as a lay judge helps younger members build their relational capital (as explicitly suggested in the flyers aiming to attract new candidacies) and opens doors for future positions in economic institutions namely the Chamber of Commerce, arbitration courts and the Conseil économique et social, an advisory board to the Prime Minister. Serving at the commercial court has traditionally been considered a 'chore' to be rewarded later on with such positions (Lemercier, 2003); further, lucrative contracts and missions are sometimes given on a discretionary basis by the acting president of the court to former judges to advise companies on a 'preventive' basis.

Consular courts are widely thought to be a cheaper and faster form of justice than a system with professional judges. Business bears more of the costs of its own governance, so that backlogs and waiting time are reduced relative to other courts; for example, there is neither jurisprudence, nor published cases. Another alleged advantage of this arrangement is that by their own business experience, lay judges are more likely than professional judges - who are civil servants - to understand the problems of entrepreneurs and to monitor satisfactorily the behaviour of company directors, particularly in cases of insolvency and bankruptcy (Carruthers and Halliday, 1998). Finally, lay judges are more likely to be familiar with idiosyncratic norms and customs (called usages in French commercial courts) based on traditional industry subcultures and contributing to organizing business practice, but often ignored in business law. Lay judges are thought to be in a better position to fine-tune norms and customs to unstable or changing business environments, and to foster regulatory innovations.

Thus French commercial courts have features that bring to light important aspects of the link between legal (exogenous) and social (endogenous) mechanisms in the governance of business. The state does not enforce and sanction alone, but requires the participation and adherence of individual and corporate actors. In effect in this case, elected representatives perform a function usually considered to be a state function, although they may also represent corporatist interests. This form of joint governance can be understood as industry self-governance with some oversight and ratification by the State (Grabosky and Braithwaite, 1986).

\section{Consular Judges Between General and Particular Interests}

The main challenge facing the system is the potentially difficult separation between general and particularistic interests. The institution officially assumes that judges will be entirely dedicated to their public mission; and 
judges themselves declare that once elected, they feel independent from their industry of origin and fully impartial. In principle, this is consistent with the business community's need for speed and decisiveness, a low number of appeals, sharp segregation of politics and personal patronage from judicial decision-making and as much neutrality as possible. However, the public has always suspected that elections of judges are politicized so that they then fail to distance themselves from their virtual 'constituency', the industry that endorsed their candidacy for the job. Especially in small towns, litigants' confidence in the impartiality of local commercial courts is often impaired. ${ }^{5}$

Indeed consular courts are sometimes thought to offer sectors of the business community, led by their syndicats patronaux (employers' associations) the opportunity to represent, or even to prevent damage to, the interests of their industry. Being at the court is a way of defending the customs of an occupation or profession. For example, the financial industry sees arrangements for corporate liquidation or administration as very important to its practice of commercial lending. Bankers could easily handle their affairs concerning corporate rehabilitation outside of courts if they perceive them as incompetent or opposed to their interests. Courts must often conform to the expectations of the financial industry or lose much of their business (Carruthers and Halliday, 1998: 488). The 'quality of justice' as defined by the financial industry (limiting risk and permitting failures, or extending credit and aid reconstruction) is a significant factor in its strategy. Representation at the court also signals to the constituency that the leaders of their syndicat are promoting the interests of the profession.

Thus from the perspective of each industry, consular judges are sometimes seen as judicial entrepreneurs (McIntosh and Cates, 1997) representing the sensitivity of the syndicats patronaux and organized interests that helped them into the courthouse in the first place by endorsing their candidacy. They are entrepreneurs because they are expected to identify problems and support solutions that make sense in their own business community - although judges themselves are often uncomfortable with the idea of being 'representatives' with a mandate from a specific industry.

Industry has attempted to influence courts in various ways. Flemming (1998) lists five such ways: jurisdiction (the range of disputes over which the court has authority), positions (actors formally authorized to participate in the disposition of cases), resources (the capacity to influence the decisions of other actors), discretion (the range of choices available to actors) and procedures (rules governing courtroom processes). Parties involved in that contest are not always directly involved in all the conflicts that are dealt with by the court, but they may have indirect concerns, material or symbolic, in the decisions of the court, which explains their efforts to influence. 
Legal systems are often designed to protect judges from external influences, for instance through well-defined procedures and an appropriate system to manage conflicts of interest. However, these forms of protection are less likely to be effective in the case of elected judges than with career judges.

\section{Over-representation of the banking and financial industry among the judges} In principle, this system of joint governance is more efficient when judges represent as many sectors as possible, so that they can bring in experience and expertise in various areas of economic activity. Indeed all the syndicats patronaux are allowed to present candidates to the elections of consular judges, but some sectors do so more systematically than others: the banking and financial industry is by far the most active, followed by services and construction.

These three industries are traditionally very litigious (Cheit and Gersen, 2000). The business docket in France is dominated by contract disputes and debt collection issues. A sizable portion of this docket involves the financial industry, for example in cases involving high levels of credit, thereby providing a strong incentive for it to invest in 'judicial entrepreneurship' (McIntosh and Cates, 1997). It also involves the construction industry which is structured as a cascade of subcontracting deals with strong incentives for conflict. These industries have high amounts of resources at stake in these conflicts. They are willing to play for the rules and endeavour to influence the court so as to impose their norms and practices over those of other industries. Their priorities can thus be defended in both the litigation and the bankruptcy benches.

The banking and financial industry is over-represented at the Commercial Court of Paris. When we conducted our fieldwork, from 2000 to 2005, it represented 3 per cent of the active population in France ${ }^{6}$ and 5.1 per cent in Paris. ${ }^{7}$ In terms of value added to the economy per branch (chained prices for previous year, 1995 basis), the share of the financial industry in the total value added to the French economy was 5.3 per cent. ${ }^{8}$ However at the same time, about one third of judges at the Commercial Court of Paris were from the financial and banking industry. In addition, judges from the banking and financial sector often have a formal legal education: about 60 per cent of them had a law degree at the time of our fieldwork, a much higher percentage than representatives of other industries. This suggests that judges coming from the financial sector are potential levers of that industry and that their influence on others may threaten the court's independence.

Why do other industries fail to invest as much in judicial entrepreneurship? One reason is that some very large companies prefer arbitration which is more discreet and avoids publicity. Another reason is that smaller 
syndicats, such as retail, do not have the necessary clout, resources and organization to lobby effectively.

\section{Advice networks of judges and decision-making}

The fact that one-third of the judges come from the financial industry does not mean that they make one-third of the decisions in the court. Because most decisions are made by a collegial body of at least three members, bankers may participate either in much less or in much more than onethird of the decisions. An indirect way to capture their influence is through advice interactions between judges - that is, sets of relations through which they share knowledge, ideas, values and guidance - which can be taken to set the premises of judicial decisions.

Premise setting for judicial decision-making is at the core of our approach of micro-level knowledge sharing. Solutions to problems ultimately depend on how these problems are initially defined or framed, that is, how certain dimensions of a problem are highlighted while others are downplayed (Lindenberg, 1998; Lazega, 1992). Definitions of a problem that gain early acceptance among members of an organization, also including judges in a courthouse, are likely to subsequently dominate in the search of a solution. Indeed sentencing is often shaped by the kind of information that is included in pre-sentence reports, which cover precisely the definition of the situation and the framing of the problem. Some judges have the status and authority to have their views taken seriously from the very beginning, and they can be decisive with respect to who is likely to win. The extent to which they are in a position to exert such an influence depends on how they have carved out a place for themselves within the court. Theories of social exchange have stressed how the circulation of intangible or immaterial resources such as knowledge is closely tied to status games (Blau, 1964; Lazega, 1992): they thus suggest that reaching influential positions largely depends on judges' interactions with their colleagues, and thus on the functioning of the court as a community of members. In this perspective, patterns of advice seeking in the court show who is prepared to listen to whom when framing and defining problems in the judicial decision-making process.

Another way to see the importance of advice networks is to conceive of the court as a form of collective competence in which members, coming from diverse professional backgrounds, pool and share their experience and expertise in order to cope with a broad range of cases, some of them very complex. This is consistent with the sociological view of competence as a distributed, capitalized property in a process of collective learning, rather than as a purely individual capacity. Mutualization of competence can be seen as a form of corporate social capital (Leenders 
and Gabbay, 1999) and includes both formal and informal consultations among judges. ${ }^{9}$ Formally, the deliberation procedure obviously provides opportunities to share knowledge; informally, judges also consult with one another intensely in areas of law and economics that they may not master equally well. While data about formal deliberations are not available, advice networks can still be mapped to provide insight into the informal component of this process.

The literature on advice networks has shown that especially within organizations, they are often shaped by a variety of influences, including the formal organizational chain or structure of the institution itself, and the normative orientation of members, to which we need to add in our case, pressures from corporate interests. Along these lines, our study of joint regulation focuses on how these three factors contribute to shaping the advice network at the court, with the idea that advice networks affect the normative orientation of the court and eventually its decisions.

\section{Fieldwork at the Commercial Court of Paris}

Fieldwork was conducted at the Commercial Court of Paris in 2000, 2002, and 2005. This court is one of the largest in France and handles around 12 per cent of all the commercial litigation in the country. It includes 21 chambers, some generalist and other specialized. The main distinction is between bankruptcy and litigation chambers, but many sub-specialties also exist (for example unfair competition, European law, multimedia and new technologies, and so on). Judges rotate yearly across chambers; each chamber has a president who reports to the president of the court.

Data on advice seeking among judges were collected at all three waves with the following name generator:

Here is the list of all your colleagues at this Court, including the President and Vice-Presidents of the Court, the Presidents of the Chambers, the judges, and 'wisemen'. Using this list, could you check the names of colleagues whom you have asked for advice during the last two years concerning a complex case, or with whom you have had basic discussions, outside formal deliberations, in order to get a different point of view on this case. ${ }^{10}$

A very high response rate (over 80 per cent) enabled us to reconstitute the complete advice network among judges at this courthouse at each of the three waves. We also collected data about judges' attributes, most notably their professional and educational backgrounds as well as their formal position and tenure at the court.

In 2005, we included a set of new questions on how judges use their business experience to accomplish their tasks. Our goal was to identify some of the norms, customs and practices on which they rely on in 
order to make decisions, particularly when they can use their discretionary authority. ${ }^{11}$ This is a difficult question because judges tend to say little about their work in order to protect their independence. To get around this difficulty, we used a jurisprudential method asking judges to comment on decisions made by other courts. These cases were deliberately chosen in areas where the law does not provide any clear-cut solution and judges must use their personal appreciation, a form of assessment that potentially calls upon norms and practices they may have learned in their industry of origin. In other words, we aimed to mobilize the judges' discretionary power in order to identify different collective tendencies.

Variation in responses is not surprising in itself since we intentionally chose cases allowing for a great deal of discretion. What interests us first and foremost is the extent to which variation in assessments drives the evolution of collective learning at this court, and thus indirectly influences decisions. We measure this effect by looking at the extent to which sharing assessments drive the evolution of the advice network among judges. We focus in this chapter on a specific case: that of litigation between majority shareholders represented by the board of a company and minority shareholders over the right of the latter to delay an Extraordinary General Assembly in which the board wanted to recapitalize the firm. The interest of this case is that, insofar as judges were asked to evaluate the decisions of a board, it measures their interventionism in the operations of a company, thereby capturing an important aspect of this form of joint governance of the economy. This case is presented below.

\section{DEALING WITH CONFLICTS BETWEEN THE BOARD AND MINORITY SHAREHOLDERS}

The case we used refers to specific clauses of the New Code of Civil Procedure (article 873, paragraph one, number 10), about judges' power to stop 'obviously illicit trouble'. The minority shareholders of a company asked a commercial court to postpone an Extraordinary General Assembly and to appoint an expert to check the refinancing operation decided by the board. Judges have discretionary power as two potentially conflicting principles inform French corporate law in this area: on the one hand, courts have the mission to protect the collective interest of the company (its survival) independently of the parties, but on the other hand, they should not interfere with its management. With this in mind, we asked Parisian commercial judges to comment on the following judgment (see Box 3.1), published by another French court. 


\section{BOX 3.1 WITH RESPECT TO MINORITY SHAREHOLDERS' RIGHT TO DELAY AN EXTRAORDINARY GENERAL ASSEMBLY}

The shareholders in the minority group (from here on designated 'the Plaintiffs') of a company (from here on designated 'the Company') looking to decrease then reconstitute its own capital, which has become inferior to half its original amount, are suing the Company in emergency proceedings.

The Plaintiffs ask for an emergency ruling from the President of the Court, first that he postpone sine die the Extraordinary General Assembly meant to carry out this recapitalization, until an expert report is made available on why the capital of the firm has become inferior to half its original amount; and second that he designate an expert to investigate the financial situation of the Company, in particular:

- The state of its losses,

- The value of its assets and shares,

- The value of the Plaintiffs' participation in the Company.

The Plaintiffs also want the appointed expert to give his opinion about the appropriateness of the financial operations examined in the board's report and about the schedule proposed by board executives for these operations.

The President of the Court decides that the conditions required for designating a management expert are met because:

- The CEO of the Company had a personal interest in the operation and made a decision as an executive of the Company;

- The Company failed to communicate specific information to the Plaintiffs in response to their questions.

Furthermore, the Court states that bringing in an expert is in the interest of all shareholders, whether or not they belong to the majority. In addition, the Court considers that some of the claims that the Plaintiffs make against the Company are valid, in particular: 
- The shareholder pact seems not to have been respected;

- The modalities of capital operations, notably the fact that the incorporation of reserves began after the reduction of capital, following an increase in capital in cash, seems not to have been clearly justified.

Taking all these elements into consideration, the President of the Court decides to postpone the Extraordinary General Assembly and selects an expert to report on the management of the Company.

Cases of this type are quite frequent at the Commercial Court of Paris every year, notably at the end of June, when companies must have their general assemblies. Postponement is risky for a company. In this case minority shareholders wonder if they will have to reach for their wallets even if they are not required to participate in the recapitalization operation, or see the value of their shares decrease. One judge speaks of the minority shareholders' worries vis-à-vis the majority:

[I]t's also a matter of knowing whether the majority shareholders are suddenly reducing their capital in order to bring in new shareholders, if in reality there are ulterior motives behind the operation. The supposed increase of capital would be made to get rid of the minorities and to gain control without them. In this case, if the transaction only tries to exclude the minorities, it would be an abuse of power by the board. If it is not a hidden entrance of a third party, the case is then limited to a quieter hypothesis.

Three-quarters of the consular magistrates responded that they would have made the same decision as the president of this court concerning the designation of an expert. The same proportion would have postponed the general assembly. Here are excerpts of interviews justifying this decision:

Minority shareholders have the right to ask questions, and we need to answer them in a very precise manner. If this isn't done, first of all it's a mistake. Secondly, a judge can't determine everything immediately. Why, because if you have to look at two years worth of balance sheets . . . you need time. We can't rule with the few elements we have. So I'd almost say, at the beginning, you'd need to bring in a finance expert who could look at all of that, who'd analyze the reports of the Commissaire aux Comptes, to find out if the procedure was properly carried out, if management did everything that there is to do ... So it's crucial to appoint an expert. 
Business obeys a type of mathematical science: game theory. When the CEO of a company is attacked like that, he's got to know about it beforehand. Or he's a bad president. The judge knows that he knows. . . . [T] he judge says to himself: 'We know that you know, buddy. You took a risk.' He's the one who managed things badly, it's not our intervention of justice. The guy willingly made a mistake and the expert will make a decision about it.

The fact that most judges would have made the same decision and pushed back the Extraordinary General Assembly does not however constitute a systematic defence of minority groups:

There's an article in the Code that allows minorities to ask for what they call a minority assessment. And the Appeals Court is even more lax than we are. In one important case, an association of shareholders that was far from holding five per cent, asked for minority assessment. They based their demand on a very general article stating that one can ask for an assessment before attaining five per cent. We refused with the reasoning: we don't want to base our decision on a far-reaching general article that could end up short-circuiting a statute for a very unique case. But for us: 'you have the 5 per cent, you have precise questions, we accept the assessment'.

The minority of judges who would not have come to the same conclusion as the court do not distinguish themselves from the others in relation to their seniority in the institution, their type of activity, or their degrees. Their arguments reveal a relationship to the law and to judges' competences that deserves further analysis:

No, we would have said: did your assembly meet regularly? That's the only thing that we need to look at, and when it's been considered, if the elements that need to be provided are not the right ones, we'd have to take it back. But not before, we don't need to intervene in the management of a company, except to enforce procedural rules. . . . If the majority decides to make this transaction [re-capitalization], with the quorum and the conditions of validity, if the others suffer losses they can sue for damages. But we wouldn't say the Court has the power to postpone a general assembly. It's a big deal!

It's better to hold the EGA as soon as possible so that the capital itself can be reconstituted. If I'd been judge we would have demanded a written communication of the Commissaire aux Comptes' last two reports for the last two years ... [D]oes he think it's useful and necessary to postpone? If not, we need to hold the EGA immediately. We're risking bankruptcy.

Luckily it's rare that just any small shareholder asks for an expert because he doesn't know what's happened in the company! Subject to all this, the demand seems excessive to me and even a little paralyzing. In any case you have to have an EGA . . . Maybe the small shareholders didn't want to follow the increase of capital and they decided to wage war against the big shareholders. But in this case you would sell your shares! It's the type of initiative that you definitely shouldn't encourage and multiply! At any moment, anyone can block 
the functioning of a company. In the case of embezzlement or fraud, we would understand. Is this really well founded or is it petty vengeance against a director with whom we can't sympathize coming from where, about what?

As soon as the magistrates leave the specific case to examine more general principles and to respond to the question of whether they should give preference to the common interest of a company, consensus disappears. Nearly the majority shares this opinion ( 46 per cent), while a quarter is hostile to it (22 per cent); the rest are hesitant (21 per cent) or refuse to answer (10 per cent). The fact that 22 per cent do not wish to give preference to the collective interest of the firm shows that the question of governance is very easily politicized.

The Court makes its verdicts based on the law. If the little guy's right, he gets the favourable solution. Survival of the company in itself is not a goal if it's at the expense of shareholders because by that logic it would be like favouring tenants over landlords, like in the USSR, where it was the State. We give verdicts to say who's wrong. If they come to the Court, it's because they already believe that in this conflict the survival of the company is at stake.

Notice that judges with a law degree and who belong to the banking and financial sector differ slightly from their colleagues in their appreciation of the decision of the court. They are more inclined to favour the collective interest of a company than the others, and less hostile to intervention in the management of a company, so that they tend to have a more 'pro-intervention' position than the rest of judges. We see the opposite for judges from the construction industry: they tend to adopt a less "prointervention' attitude than the rest of the judges in litigation opposing the shareholders of a company.

\section{MODEL FOR ANALYSIS}

The outcome variable in our study is the selection of advice ties by judges, and we focus on the evolution over time of the network composed by these ties. We use the stochastic actor-oriented approach of Snijders (2001), with the software Siena version four, a package in the $\mathrm{R}$ statistical environment (Ripley and Snijders, 2010). The model postulates that the existing network structure has effects on changes in selection of advisors, specifies these effects, and takes into account interdependence between ties. (For a more extensive treatment, see Snijders 2001, 2005; Snijders et al., 2010).

\section{Model Specification}

The model presents the evolution of the network from its state at the first observation to that observed at the second observation, and likewise the development from the second to the third observation, and so on. This 
evolution is presented as consecutive changes of advisor choice, which can be of three types: (1) creation of new ties (that is new advisor choices); (2) termination of existing ties (that is dropping advisors); or (3) maintenance of existing ties. These changes are assumed to occur sequentially between the observations, and actors are assumed to be aware of them and thus to have knowledge of the changing network. This first-order approximation is reasonable as the commercial court is a relatively small institution composed of about 150 members at each moment in time. Each of the changes of advisor is regarded as a choice made by the judge requesting advice. The probability distribution of these choices is modelled as being dependent on the so-called objective function, which is a function of the personal network of the member making the current choice.

Probabilities of change are higher toward network states having a higher value of the objective function; thus, the objective function can be loosely regarded as representing the attractiveness of the network, as seen from the viewpoint of the member concerned. The objective function is a linear combination of terms called 'effects', similar to the linear predictor in generalized linear modelling. The weights of these effects are the parameters in the statistical model, and are estimated from the data. Each effect represents a component potentially driving the network dynamics.

To state the model formally, suppose there are $i=1,2, \ldots, n$ actors and call $X_{i j}$ the potential tie from actor $i$ to actor $j$, which may have value 0 (absence) or 1 (presence). Assume that with a given frequency, actor $i$ is given an opportunity to change from $X_{i j}$ to $1-X_{i j}$. Furthermore, assume that actor $i$ makes changes that maximize its objective function $f_{i}(b, x(i \rightarrow j))$ (where $\mathrm{x}$ is a matrix representing the whole network of ties, $\mathrm{b}$ is a vector of statistical parameters, and $x(i \rightarrow j)$ is the state of the network when $X_{i j}$ becomes $1-X_{i j}$ ), plus a random disturbance with Gumbel distribution, as in random utility models. Under these conditions, the probability that such a change occurs is:

$$
p_{i j}(\beta, x)=\frac{\exp \left(f_{i}(\beta, x(i \rightarrow j))\right)}{\sum_{h=1}^{n} \exp \left(f_{i}(\beta, x(i \rightarrow h))\right)}
$$

This is the multinomial logit form of a random utility model. The statistical inference aims to estimate the parameters $b$, which indicate the preferred direction of changes, by a generalized method of moments.

Some of the parameters refer to endogenous effects that depend on the network itself: they represent dependency between network ties and account for path-dependency in network evolution. Others are related to exogenous effects and depend on the characteristics of the member 
making the choice and/or the member chosen. The model specification consists of specifying both the endogenous and the exogenous effects that are hypothesized to drive the dynamics of the network. This specification must include effects reflecting the hypotheses but also effects reflecting other mechanisms thought to drive network dynamics, in order to rule out alternative explanations (similar to control variables in regression models) and to provide a good model fit so that the standard errors of the parameter estimates are reliable.

\section{Estimation Methodology}

The effects included in the model are meant to explain network change, that is, the selection of advice ties by judges. Let us start with endogenous effects which, as mentioned earlier, account for path-dependency and can be regarded as controls, necessary to understand the dynamics of the network.

To begin with, we control for the effect of local sub-structures which are well known in the social networks literature to be likely drivers of the evolution of networks. Reciprocity captures the tendency for an actor to form an advice tie with those who seek advice from him or her, and is reflected in the objective function by the number of mutual ties of each given actor $i$. The transitive triplets effect refers to the propensity to seek advice from one's advisor's advisor, and is defined by the number of transitive patterns in actor $i$ 's relations, that is, ordered pairs of actors $(j, h)$ to both of whom $i$ is tied, while $j$ is also tied to $h$. The three-cycle effect captures a tendency for the formation of short cycles of generalized exchange and depends on the number of three-cycles in $i$ 's personal advice relationships, that is, cycles in which $i$ seeks advice from $j, j$ from $k$, and $k$ from $i$. The conjunction of a positive transitive triplets effect accompanied by a negative threecycles effect may be regarded as a form of local hierarchy in advice.

In addition, we control for global structures depending on degrees. In social network analysis, in-degrees measure the number of incoming ties, and in-degree centrality captures the extent to which a judge is identified by others as one of their advisors; it can be interpreted as a form of popularity or status. Conversely, out-degrees measure the number of outgoing ties, and out-degree centrality is the number of advisors of a judge. These measures are relevant because the distribution of both in- and out-degrees is highly skewed in this particular network (Lazega et al., 2008, 2010a) and must be controlled adequately in order to obtain a good model fit. As proposed in Snijders et al. (2010), we include three degree-related effects relating to, respectively, the dispersion (variance) of in-degrees, the association (correlation) between in- and out-degrees and the dispersion 
(variance) of the out-degrees. First, in-degree popularity (sqrt) is defined as the sum of the square roots of in-degrees of a judge's advisors; a positive parameter for this effect indicates that judges with higher in-degrees are more attractive as advisors, and hence indicates a self-reinforcing effect leading to high dispersion of in-degrees. The square roots are used because we assume that a higher in-degree increases attractiveness of an advisor (monotonicity), but its impact becomes lower at higher values of the indegree (decreasing marginal effect). Second, out-degree popularity (sqrt) is the sum of the square roots of out-degrees of a judge's advisors. When this effect is positive, judges with higher out-degrees are more attractive as advisors, resulting in a relatively high association between in-degrees and out-degrees. Again, the use of a square root measure presumes that differences between high out-degrees are relatively less important than the same differences between low out-degrees. Third, out-degree activity (sqrt) is defined as the out-degree of a judge times the square root of his/ her own out-degree. If its parameter is positive, judges who currently ask many others for advice will have - compared to those who ask few others for advice - a relatively stronger tendency to add a new advisor rather than drop an old advisor. This is, again, a self-reinforcing effect: a positive parameter will lead to increased dispersion of out-degrees. In a previous paper (Lazega et al., 2010a) we interpreted degree-related effects as indicators of status that, over time, sustain the centrality of judges with high in-degrees and low out-degrees.

Notice that the in-degrees and out-degrees have the dual role of independent variables, and reflections of the dependent variables, that is the tie changes. This raises no logical issues because these two roles are separated in the dynamic model that we use: at any moment in time the current indegrees are among the predictors for creation of new ties and maintenance of existing ties. Such a dual role is characteristic of models with feedback.

We also include exogenous variables, that is attributes of actors or pairs of actors. For the actor-level variables, we estimate the following basic three effects (see Snijders et al., 2010): ego effects to account for their advice-seeking behaviour, alter effects for being sought out for advice and similarity effects. A positive ego parameter would indicate that judges with these characteristics have a greater tendency to seek advice than others; a positive alter parameter would indicate that others have a greater tendency to seek advice from such judges; and a positive similarity effect would indicate that judges who are similar with respect to this attribute (both having it or both not having it) have a higher tendency to seek advice from each other.

The main variable of interest is judges' view of the case of shareholder conflict presented above, which we take as an indicator of their 
interventionism in boards; we represent it as a dummy variable. The other important variable of interest is the professional and educational background of judges. In line with the above discussion, we distinguish those from the banking and financial industry, and with legal education, from all others.

As a control, we also include judges' seniority, that is, number of years spent at the court, a proxy for position in the hierarchy: indeed some roles such as president of chamber can only be awarded to judges who have at least eight years of experience at the court. Another organizational aspect that we control for is chamber co-membership at the time of fieldwork and chamber co-membership during previous years, reflecting the division of labour in the court and the fact that two judges who are, or were in the past, in the same chamber are likely to have closer or more frequent contacts, and this may be reflected in their choice of advisors. Technically, chamber co-membership and previous chamber co-membership are changing dyadic variables, for which the changes keep track of new co-memberships between the first and the second periods of observation (2000-2002 and 2002-2005 respectively).

\section{Parameter Estimates}

Table 3.1 presents our results. We use a large dataset including all judges who were present at the court at least once in 2000, 2002 or 2005, plus those who were 'wisemen' in these years. This is a network with changing composition, whose members are partly renewed every year as judges who have finished their mandate leave and are replaced by newcomers, with a turnover of about 10 per cent. In this sense, this model is an extension of our previous work which only relied on the subset of judges who were present at all three waves (Lazega et al., 2008, 2010a). We fit the model separately for the two periods (2000-2002 and 2002-2005) to take into account differences in composition, average degree and other network characteristics over the waves, which might otherwise impair the quality of estimates (Lospinoso et al., 2010). This is needed all the more as the degree distribution in our dataset is much more skewed, thus leading to higher centralization, in Period One than in Period Two (Lazega et al., 2006; 2010b).

The rate parameter accounts for the amount of change between two subsequent observations of the network, that is, the speed at which the dependent variable (the network) changes. All other parameters are coefficients of the objective function or network evaluation function, used to compare different states of the network when the actor makes a choice to maintain present ties, to add a new tie, or to delete an existing tie. If 
Table 3.1 Bankers' norms drive the evolution of the advice network among lay judges at the Commercial Court of Paris (Siena model)

\begin{tabular}{|c|c|c|c|c|}
\hline & \multicolumn{2}{|c|}{$\begin{array}{l}\text { Period One } \\
(2000-2002)\end{array}$} & \multicolumn{2}{|c|}{$\begin{array}{l}\text { Period Two } \\
(2002-2005)\end{array}$} \\
\hline & Estimate & $\begin{array}{l}\text { Standard } \\
\text { error }\end{array}$ & Estimate & $\begin{array}{c}\text { Standard } \\
\text { error }\end{array}$ \\
\hline Rate parameter & 31.9 & 2.61 & 21.53 & 0.96 \\
\hline Out-degree (density) & $-4.29 *$ & 0.28 & $-3.3 *$ & 0.25 \\
\hline Reciprocity & $0.56^{*}$ & 0.16 & 0.36 & 0.22 \\
\hline Transitive triplets & $0.14^{*}$ & 0.04 & $0.19 *$ & 0.03 \\
\hline 3 -cycles & $-0.19^{*}$ & 0.1 & -0.03 & 0.05 \\
\hline In-degree - popularity (sqrt) & $0.4^{*}$ & 0.02 & $0.34^{*}$ & 0.02 \\
\hline Out-degree - popularity (sqrt) & $-0.19 *$ & 0.1 & $-0.19^{*}$ & 0.1 \\
\hline Out-degree - activity (sqrt) & $0.38^{*}$ & 0.04 & $0.08^{*}$ & 0.04 \\
\hline Chamber co-membership & $1.21 *$ & 0.08 & $1.68 *$ & 0.09 \\
\hline Previous chamber co-membership & $0.8^{*}$ & 0.08 & $0.25^{*}$ & 0.1 \\
\hline BankLaw alter & $0.14^{*}$ & 0.07 & 0.09 & 0.08 \\
\hline BankLaw ego & $-0.18 *$ & 0.08 & $-0.25^{*}$ & 0.08 \\
\hline BankLaw similarity & 0.07 & 0.07 & 0.09 & 0.08 \\
\hline Seniority alter & $0.04 *$ & 0.01 & -0.01 & 0.01 \\
\hline Seniority ego & 0.01 & 0.01 & $-0.03^{*}$ & 0.01 \\
\hline Seniority similarity & 0.12 & 0.23 & -0.22 & 0.29 \\
\hline Interventionism in Boards alter & $0.15^{*}$ & 0.06 & $0.13 *$ & 0.05 \\
\hline Interventionism in Boards ego & 0.09 & 0.07 & 0.04 & 0.05 \\
\hline $\begin{array}{l}\text { Interventionism in Boards } \\
\text { similarity }\end{array}$ & 0.01 & 0.09 & 0.03 & 0.07 \\
\hline
\end{tabular}

Note: *statistically significant at 5 per cent level.

a parameter value is nil, the corresponding effect does not drive network dynamics; if it is positive, then there will be a higher probability of moving toward a personal network where the corresponding variable has a higher value; and the opposite if it is negative.

Among endogenous structural effects, the density effect is a basic indicator of network density and can be interpreted as an intercept. At local level the reciprocity effect is not always significant and does not allow concluding that judges tend to seek advice from those who themselves sought advice from them. The transitive triplets effect is positive and significant while the three-cycles effect is not consistently significant over time, so that we cannot conclude that there is local hierarchy in advice.

Endogenous feedback mechanisms at global rather than local level are captured through degree-related effects. We include in-degree popularity, 
out-degree popularity and out-degree activity, all in square root form. Indegree popularity is positive and statistically significant: it is evidence of a self-reinforcing process in which judges who are central at a given point in time see their centrality grow more strongly than others. Out-degree popularity is negative and suggests that judges with high out-degrees are less sought for advice, and the system moves towards a relatively low correlation between in- and out-degrees. Finally, out-degree activity is positive and significant (though more strongly so in the first than in the second period), suggesting that those who seek much advice remain in this role, and that the dispersion of out-degrees becomes or remains relatively high.

Regarding the exogenous variables, it is clear that chamber comembership plays an important role in shaping the advice network, as already pointed out in our previous studies (Lazega et al., 2006, 2008). Previous chamber co-memberships also matter, even though their effect is smaller in size, indicating that some ties are lost with job rotation. Most of the other parameters exhibit time heterogeneity and do not display the same tendency over time. For instance, bankers with a law degree are particularly attractive as advisors in Period One (positive and statistically significant alter effect), but not in Period Two; their own advice-seeking behaviour is no different from that of other judges in Period One, but they tend to consult others less in Period Two (negative and significant ego effect). Likewise, more senior judges are attractive advisors in Period One but not afterwards, while the tendency of seniors not to seek advice from those more junior than themselves is only detectable in Period Two. These differences seem largely due to the changing composition of the network: indeed, senior judges and bankers-lawyers appear to remain consistently differentially attractive as advisors over time when only the sub-set of judges who responded to the survey at all three waves is considered (Lazega et al., 2008, 2010a).

Interestingly, however, the 'Interventionism in Boards' alter parameter is positive and statistically significant over the two periods, thereby suggesting that judges who shared the decision to postpone the General Assembly and to appoint an expert have a consistently higher tendency to be consulted by others, so that their in-degree centrality becomes, or is, relatively high. Instead, the ego and similarity parameters are not significant. Hence, consensus on this choice contributes to driving the evolution of the advice network among judges at the Commercial Court of Paris and can be considered as a likely determinant of its final regulatory and judicial orientations. Since bankers with a law degree tend to be more interventionists in boards, on average, than the other judges, it is very likely that it is their influence that is being measured here with this effect. Thus the dominance of bankers-lawyers - through their interventionist views 
with respect to boards, rather than through their sheer presence - extends to the court as a whole.

\section{CONCLUSIONS}

In this chapter, we have discussed a form of joint governance of the economy in which the government delegates important functions to civil society - here representatives of business acting as lay judges at a truly judicial commercial court. We outlined how this arrangement, despite its advantages in terms of effectiveness and efficiency of the conflict resolution process, entails the risk that particular industry interests prevail over the general interest. In particular it is known that the financial and banking sector as well as, to a lesser extent, the construction and services industries take strong action to ensure that their interests are taken into account.

Yet consular courts are complex structures in which sheer representation of the interests of specific sectors does not per se lead to dominance of these sectors. Final outcomes depend also upon the organizational features of the court, that is its structure in chambers and its internal hierarchy, and on the normative orientations of its members - in particular, we focused here on judges' pro-interventionist view in matters of company management at the board level. We investigated how these factors contribute to shaping the advice network at the court, that is the channels through which knowledge, norms, ideas and guidance circulate. The interest of this approach is that it confirms that advice networks affect the overall normative orientation of the court, and eventually its decisions.

Our Siena model provides evidence that adherence to a prointerventionist (in boards) view is a driver of the evolution of the advice network. This is consistent with the observation that most judges agreed with the decision to accept the request of minority shareholders that they were asked to comment as a jurisprudential case. Despite variation in their answers, they find pro-interventionist colleagues more attractive as advisors, and do so consistently over time. The only other clear trend is, among organisational variables, chamber and previous chamber co-membership as a consistently strong driver of network dynamics.

However, the fieldwork suggests that differences in opinion remain strong and that, although judges agreed on the particular case they commented, they were not all ready to generalize it and protect minority shareholders in all circumstances. Further, there were nuances in judges' appreciation even of the most consensual answer, owing largely to the sector of activity of origin as bankers appeared more inclined to interventionism in boards than executives from the building industry. 
These results support a sociological interpretation of joint governance as a multifaceted system, in which particular industries can have an influence not only by sending many judges in, but also more subtly by exerting persuasion through informal advice ties. They shed light on some of the risks of institutional capture (Lazega, 2009) attached to such an institutional design, but also on the complexity of the concept of joint governance of markets.

As underlined by Dixit (2009), governance equilibria identified in theory by many economists can fall short of social optimality for many reasons. Our findings show that 'joint governance', not to mention 'self governance' or Dixit's 'private-ordering governance institutions', can also represent suboptimal solutions with respect to public interest. Even official governance institutions that are efficient in terms of speed can be suspected of harbouring conflicts of interests with private intermediaries. Our case study shows that, when contributing to official enforcement in governance, business relies on its most powerful segments (representatives of the banking industry for example) that act as a third party and distort such enforcement in invisible ways to suit its own interests rather than social welfare. Therefore, we conclude by pointing to the possibility that relation-based and rule-based modes of governance can be combined in suboptimal ways that allow certain parties to 'cheat' more easily, to protect their rent and power or to double cross any other party in a conflict - simply by knowing that privately-selected officials acting as third parties are socially closer and intellectually more sensitive to these private interests.

\section{NOTES}

1. Since Max Weber's study of the German nineteenth century Börse (2000[1924]), organizational sociologists' works on economic institutions have greatly contributed to economic sociology. Some of them, such as Baker (1984) in his study of the Chicago Options Exchange, have added a structural spin to organizational approaches (White, 2002; Swedberg, 1994).

2. Arbitration also exists as a formal avenue of conflict resolution for businesses, but it is usually much more expensive and therefore limited to large and multinational companies.

3. For the characteristics of the French system of commercial courts as an institution of combined external and self-regulation, see Chaput (2002), Hirsch (1985), Ithurbide (1970), Jean (2000), Szramkiewicz (1989). There are 191 commercial courts in France, around 3,000 consular judges making approximately 300,000 judicial decisions each year, of which 50,000 concern insolvency issues (Ministry of Justice figures for 1998; www.justice.gouv.fr/publicat/tc1807.htm (accessed 10 June 2010).

4. Two months after we began fieldwork, French commercial courts went on strike, for the first time in their history, against a proposed 2001 reform of their system. At the Commercial Court of Paris, we were surprised to see so many judges haunting the 
corridors of the building during weeks of strike: many were retired, 'all dressed up with no place to go' as their younger colleagues said.

5. The state strives to increase its control. Since 1981, the attorney general has had an office at the court and is allowed to participate in deliberations, especially in bankruptcy proceedings. In 2001, a draft law was debated in the National Assembly and the Senate which aimed at introducing professional judges in the midst of consular judges, as a means to reassure businesses involved in court proceedings by improving 'control over the controllers'. The reform eventually failed but is indicative of a paradoxical situation. It was when the state began to withdraw from direct control of the economy in the 1980 s that it started its attempts to increase its presence in commercial courts. The justification for this change in policy is to reassure European and global investors that they will receive a fair treatment in French commercial courts. This explanation, however, must be taken with caution: in spite of decades of selling its holdings, the French state's direct ownership in the economy remains strong.

6. Source: Labour force survey (Enquête Emploi) 2000, Institut national de la statistique et des études économiques (INSEE).

7. Source: Institut national de la statistique et des études économiques (INSEE), Mensuel no. 202, October 2001, Ile-de-France: 'Gros plan sur l'emploi francilien en 1999'.

8. Source: Institut national de la statistique et des études économiques (INSEE), National Accounts, 2001 (www.insee/fr/indicateur/cnat_annu/tableaux/t_1201_25_4.htm (accessed 20 June 2010).

9. The question is whether this represents social capital at the macro level, for society as a whole. One may argue that it is the case as with consular courts, civil society participates in the political process and in the life of institutions; the existence of virtuous knowledge-sharing processes would reinforce this view. However, others may contend that social capital in consular courts may in fact promote the particular interests of some industries and business organisations, rather than the general interest.

10. Wisemen are judges whose mandate has ended but remain available as advisors for other judges.

11. In the French legal system, this discretion is called pouvoir souverain d'appréciation.

\section{REFERENCES}

Ayres, Ian and John Braithwaite (1992), Responsive Governance: Transcending the Degovernance Debate, Oxford: Oxford University Press.

Baker, Wayne E. (1984), 'The social structure of a National Securities Market', American Journal of Sociology, 89, 775-811.

Blau, Peter (1964), Exchange and Power in Social Life, New York: John Wiley and Sons.

Buskens, Vincent, Werner Raub and Chris Snijders (2003), 'Theoretical and empirical perspectives on the governance of relations in markets and organizations', Research in the Sociology of Organizations, 20, 1-18.

Carruthers, Bruce G. and Terence Halliday (1998), Rescuing Business: The Making of Corporate Bankruptcy Law in England and the United States, Oxford: Oxford University Press.

Chaput, Yves (2002), 'L'indépendance renforcée du juge économique', Revue de Jurisprudence Commerciale, Special issue: Colloque de La Baule : Le Juge de l'économie, 46, 74-94.

Cheit, Ross E. and Jacob E. Gersen (2000), 'When businesses sue each other: an empirical study of State Court litigation', Law and Social Inquiry, 25, 789-816. 
Dixit, Avinash (2009), 'Governance institutions and economic activity', American Economic Review, 99, 5-24.

Dunworth, Terence and Joel Rogers (1996), 'Corporations in court: Big Business litigation in US federal courts, 1971-1991', Law and Social Inquiry, 21, 497-592.

Ellickson, Robert C. (1991), Order Without Law: How Neighbors Settle Disputes, Cambridge, MA: Harvard University Press.

Falconi, Ana Maria, Karima Guenfoud, Emmanuel Lazega, Claire Lemercier, Lise Mounier (2005), 'Le Contrôle social du monde des affaires: une étude institutionnelle', L'Année sociologique, 55 (2), 451-484.

Felstiner, William L.F., Richard L. Abel and Austin Sarat (1980), 'The emergence and transformation of disputes: naming, blaming, claiming', Law and Social Inquiry, 15, 631-654.

Flemming, Roy B. (1998), 'Contested terrains and regime politics: thinking about America's trial courts and institutional change', Law and Social Inquiry, 23, 941-965.

Galanter, Marc and Charles E. Epp (1992), 'A beginner's guide to the litigation maze', Business Economics, 27, 33-38.

Grabosky, Peter and John Braithwaite (1986), Of Manners Gentle: Enforcement Strategies of Australian Business Regulatory Agencies, Oxford: Oxford University Press.

Greif, Avner (1996), 'Contracting, enforcement, and efficiency: economics beyond the law', Annual World Bank Conference on Development Economics, 1996, 239-265.

Hawkins, Keith O. (1984), Environment and Enforcement, Oxford: Oxford University Press.

Hawkins. Keith O. and John M. Thomas (eds) (1984), Enforcing Governance, Boston, MA: Kluwer-Nijhof.

Heydebrand, Wolf V. and Carroll Seron (1990), Rationalizing Justice: The Political Economy of Federal District Courts, Albany, NY: SUNY Press.

Hirsch, Jean-Pierre (1985), Les deux rêves du commerce. Entreprise et institution dans la région lilloise (1780-1860), Paris: Editions de l'EHESS.

Ithurbide, René (1970), Histoire critique des tribunaux de commerce, Paris: LCDG.

Jean, Jean-Paul (2000), La réforme des tribunaux de commerce, Regards sur l'actualité, Paris: La documentation française.

Lazega, Emmanuel (1992), Micropolitics of Knowledge. Communication and Indirect Control in Workgroups, New York: Aldine-de Gruyter.

Lazega, Emmanuel (2009), 'Quatre siècles et demi de New (New) Law \& Economics: du pragmatisme juridique dans le régime consulaire de contrôle social des marchés', Revue Française de Socio-Economie, 3, 97-120.

Lazega, Emmanuel and Lise Mounier (2002), 'Interdependent entrepreneurs and the social discipline of their cooperation: the research program of structural economic sociology for a society of organizations', in Olivier Favereau and Emmanuel Lazega (eds), Conventions and Structures in Economic Organization: Markets, Networks, and Hierarchies, Cheltenham, UK and Northampton, MA, USA: Edward Elgar, pp. 147-199

Lazega, Emmanuel and Lise Mounier (2003), 'Interlocking judges: on joint external and self-governance of markets', Research in the Sociology of Organizations, 20, 267-296. 
Lazega, Emmanuel, Claire Lemercier and Lise Mounier (2006), 'A spinning top model of formal structure and informal behaviour: dynamics of advice networks in a Commercial Court', European Management Review, 3, 113-122.

Lazega, Emmanuel, Lise Mounier, Tom A.B. Snijders and Paola Tubaro (2008), 'Réseaux et controverses: de l'effet des normes sur la dynamique des structures', Revue française de sociologie, 49, 467-498.

Lazega, Emmanuel, Lise Mounier, Tom A.B. Snijders and Paola Tubaro (2010a), 'Norms, status and the dynamics of advice networks', in press, Social Networks, available at http://dx.doi.org/10.1016/j.socnet.2009.12.001 (accessed 1 December 2010).

Lazega, Emmanuel, Saraï Sapulete and Lise Mounier (2010b), 'Structural stability regardless of membership turnover? The added value of blockmodelling in the analysis of network evolution', in press, Quality and Quantity, electronic version published, DOI 10.1007/s11135-009-9295-y.

Leenders, Roger and Shaul Gabbay (eds) (1999), Corporate Social Capital and Liabilities, Boston, MA: Kluwer.

Lemercier, Claire (2003), Un si discret pouvoir. Aux origines de la Chambre de commerce de Paris, 1803-1853, Paris: La Découverte.

Lindenberg, Siegwart (1998), 'Solidarity: its microfoundations and macro dependence, a framing approach', in Patrick Doreian and Thomas J. Fararo (eds), The Problem of Solidarity: Theories and Models, New York: Gordon \& Breach.

Lospinoso, Joshua A., Michael Schweinberger, Tom A.B. Snijders and Ruth M. Ripley (2010), 'Assessing and accounting for time heterogeneity in stochastic actor oriented models', Advances in Data Analysis and Computation, forthcoming.

Macaulay, Stewart (1963), 'Non-contractual relations in business: a preliminary study', American Sociological Review, 28, 55-67.

Macaulay, Stewart (1986), 'Private government', in Leon Lipson and Stanley Wheeler (eds), Law and the Social Sciences, New York: Russell Sage.

McIntosh, Wayne V. and Cynthia L. Cates (1997), Judicial Entrepreneurship: The Role of the Judge in the Marketplace of Ideas, Westport, CT: Greenwood Press.

Milgrom, Paul R., Douglass C. North and Barry R. Weingast (1990), 'The role of institutions in the revival of trade: the law merchant, private judges, and the champagne fairs', Economics and Politics, 2 (1), March, 1-23.

Raub, Werner and Jeroen Weesie (1993), 'Symbiotic arrangements: a sociological perspective', Journal of Institutional and Theoretical Economics, 149, 716-724.

Raub, Werner and Jeroen Weesie (eds) (2000), The Management of Durable Relations: Theoretical and Empirical Models for Households and Organizations, Amsterdam: Thela Publishers.

Ripley, Ruth M. and Tom A.B. Snijders (2010), Manual for Siena version 4, available at http://www.stats.ox.ac.uk/ snijders/siena/ (accessed 1 December 2010).

Rooks, Gerrit, Werner Raub, Robert Selten and Frits Tazelaar (2000), 'How inter-firm cooperation depends on social embeddedness: a vignette study', Acta Sociologica, 43, 123-137.

Shapiro, Susan P. (1984), Wayward Capitalists: Target of the Securities and Exchange Commission, New Haven, CT: Yale University Press.

Snijders, Tom A.B. (2001), 'The statistical evaluation of social network dynamics', in Michael E. Sobel and Mark P. Becker (eds), Sociological Methodology, Boston, MA and London: Basil Blackwell, pp. 361-395. 
Snijders, Tom A.B. (2005), 'Models for longitudinal network data', in Peter J. Carrington, John Scott and Stanley Wasserman (eds), Models and Methods in Social Network Analysis, New York: Cambridge University Press, Chapter 11.

Snijders, Tom A.B., Gerhard G. van de Bunt and Christian E.G. Steglich (2010), 'Introduction to stochastic actor-based models for network dynamics', Social Networks, 32, 44-60.

Swedberg, Richard (1994), 'Markets as social structures', in Neil Smelser and Richard Swedberg (eds), Handbook of Economic Sociology, Princeton, NJ: Princeton University Press; and New York: Russell Sage Foundation.

Szramkiewicz, Romuald (1989), Histoire du droit des affaires, Paris: Montchrestien. Weait, Matthew (1993), 'Icing on the cake: the contribution of the compliance function to effective financial services regulation', Journal of Asset Protection and Financial Crime, 1, 83-90.

Weaver, Suzanne (1977), Decision to Prosecute: Organization and Public Policy in the Antitrust Division, Cambridge, MA: The MIT Press.

Weber, Max (2000[1924]), 'Die Börse', Theory and Society, 29, 303-337.

Wheeler, Stanton, Kenneth Mann and Austin Sarat (1988), Sitting in Judgment: The Sentencing of White Collar Criminals, New Haven, CT: Yale University Press.

White, Harrison C. (2002), Markets from Networks: Socioeconomic Models of Production, Princeton, NJ: Princeton University Press.

Williamson, Oliver E. (1985), The Economic Institutions of Capitalism, New York: Free Press. 